\title{
IMPLEMENTASI TOPSIS DALAM PEMBERIAN REWARD GURU TERBAIK PADA SMK SWASTA 1 HKBP PEMATANGSIANTAR
}

\author{
Sahat Sonang S. ${ }^{1)}$, Arifin Tua Purba ${ }^{2)}$ \\ ${ }^{1,2}$ Teknik Komputer, Politeknik Bisnis Indonesia \\ email : sahatsonangstg@gmail.com, arifintuaprb20@gmail.com
}

\begin{abstract}
Reward is a form of appreciation received by an individual for the achievement of a work performance that aims to motivate the individual to have high productivity. In managerial terms, giving a warning is a good and reasonable thing to do by the leader to his subordinates. Likewise with the Private Vocational School 1 HKBP Pematangsiantar. This research was conducted to provide solutions to problems that occur through the design of a decision support system software for giving the best teacher reward with the Technique for Order Preferences by Similarity to Ideal Solution (TOPSIS) method with assessment components including (1) discipline, (2) involvement, (3) attendance, (4) leadership, (5) training and (6) social. The Decision Support System for providing teacher rewards is able to accommodate subjective problems, lack of transparency, and doubts about its accuracy and the output is very credible. Thus the decision-making process for giving the best teacher reward is efficient, effective and objective and can be used as a recommendation for school principals in determining which teachers deserve rewards. From the 10 data samples used, the results of the analysis using the Decision Support System show that the highest recommendation value is 0.7149 on behalf of A8, while the lowest recommendation value is 0.2851 on behalf of A10.
\end{abstract}

Keywords: Recommendation, DSS, TOPSIS, Reward

\section{PENDAHULUAN}

Perkembangan teknologi informasi yang sangat cepat mendorong terciptanya penggunaan teknologi dalam berbagai lini kehidupan manusia salah satunya dalam bidang pendidikan. Guru merupakan sumber daya manusia yang penting di dalam dunia pendidikan. Jika kinerja guru dapat dikelolah dengan baik, maka sekolah dapat menjalankan semua proses kegiatan belajar mengajar dengan baik. Saat ini penilaian kinerja guru masih dilakukan banyak dilakukan secara konvensional yang membutuhkan waktu yang lama dan penilaian kurang abjektif.

Guru atau pendidik adalah pengajar, pembimbing, melatih, menilai dan mengevaluasi peserta didik. Guru juga merupakan garda terdepan dalam pengembangan pendidikan. Seiring bertambahnya aktivitas dan beban kerja guru pada dunia pendidikan saat ini, maka perlu adanya penghargaan berupa reward sebagai penghargaan sekaligus motivasi bagi guru atau pendidik dalam menjalankan tugas dan kewajibannya. Untuk menentukan guru atau pendidik yang akan mendapatkan reward, setiap sekolah dihadapkan pada suatu keadaan pilihan dari beberapa pilihan yang ada. Penentuan ini dapat diputuskan berdasarkan kriteria yang dimiliki oleh sekolah sesuai dengan kriteria atau syarat kelayakan yang berlaku di sekolah tersebut.

Reward merupakan bentuk penghargaan yang diterima oleh individu atas pencapaian suatu prestasi kerja yang bertujuan untuk memotivasi individu tersebut agar produktifitasnya tinggi. Secara manajerial pemberian reward merupakan hal baik dan wajar dilakukan oleh pimpinan kepada bawahannya. Begitu halnya dengan SMK Swasta 1 HKBP Pematangsiantar. Namun dari informasi yang diperoleh langsung dari para guru bahwa pemberian reward guru terbaik SMK Swasta 1 HKBP Pematangsiantar masih terkesan subjektif oleh pimpinan, yang dalam hal ini Kepala Sekolah. Kepala sekolah melakukan penilaian terhadap kinerja guru kurang transparan, tidak objektif dan tidak dapat diukur dan akibatnya putusan yang diambil tidak dapat diterima oleh banyak pihak yang merasa dirugikan. 
Salah satu metode yang dapat digunakan untuk Sistem Pendukung Keputusan adalah metode Technique For Order Preference By Similarity to Ideal Solution (TOPSIS). Metode TOPSIS menggunakan konsep dimana alternatif terpilih yang terbaik tidak hanya memiliki jarak terpendek dari solusi ideal positif, namun ada memiliki jarak terpanjang dari solusi ideal negatif.[1]-[5] TOPSIS juga memiliki konsep yang sederhana dan mudah dipahami, komputasinya efisien serta mempunyai kemampuan untuk mengukur kinerja relatif dari alternatif keputusan. [6][7].

\section{METODE PENELITIAN}

Tahapan yang dilaksanakan pada penelitian ini dilakukan dengan berbagai seperti terlihat pada gambar 1 .

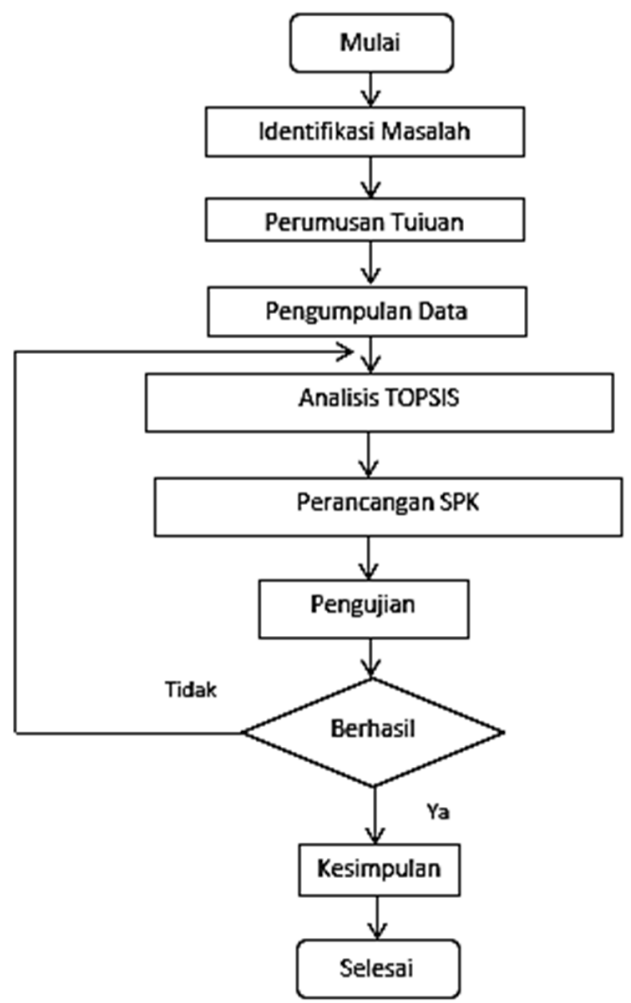

Gambar 1. Tahapan Penelitian

Kriteria yang digunakan dalam penelitian ini terdiri dari: Ketepatan Waktu, Keterlibatan, Absensi, Kepemimpinan, Pelatihan, dan Sosial.
Bobot dari setiap kriteria dapat dilihat pada tabel 1 dan nilai setiap kriteria terdapat pada tabel 2 .

Tabel 1. Data Kriteria

\begin{tabular}{clcc}
\hline No & \multicolumn{1}{c}{ Kriteria } & Bobot & Ket \\
\hline 1 & Ketepatan Waktu & 5 & $\mathrm{C}_{1}$ \\
2 & Keterlibatan & 4 & $\mathrm{C}_{2}$ \\
3 & Absensi & 3 & $\mathrm{C}_{3}$ \\
4 & Kepemimpinan & 3 & $\mathrm{C}_{4}$ \\
5 & Pelatihan & 2 & $\mathrm{C}_{5}$ \\
5 & Sosial & 1 & $\mathrm{C}_{6}$ \\
\hline
\end{tabular}

Tabel 2. Standar Nilai Bobot Kiteria

\section{Nilai Keterangan}

\begin{tabular}{cl}
\hline 1 & Sangat Rendah \\
2 & Rendah \\
3 & Cukup \\
4 & Baik \\
5 & Sangat Baik
\end{tabular}

Tabel 3. Skor Kriteria

\begin{tabular}{|c|c|c|c|}
\hline No. & Kriteria & Data Awal & $\begin{array}{c}\text { Data } \\
\text { Konversi }\end{array}$ \\
\hline \multirow[t]{5}{*}{1.} & Disiplin & $\begin{array}{l}\text { Selalu datang } \\
\text { terlambat }\end{array}$ & 1 \\
\hline & & Sering terlambat & 2 \\
\hline & & Jarang Terlambat & 3 \\
\hline & & $\begin{array}{l}\text { Hampir selalu tepat } \\
\text { waktu }\end{array}$ & 4 \\
\hline & & Selalu tepat waktu & 5 \\
\hline \multirow[t]{5}{*}{2.} & Keterlibatan & Tidak aktif dan kreatif & 1 \\
\hline & & $\begin{array}{l}\text { Kurang aktif dan } \\
\text { kreatif }\end{array}$ & 2 \\
\hline & & $\begin{array}{l}\text { Aktif namun kurang } \\
\text { kreatif/ kreatif namun } \\
\text { kurang aktif }\end{array}$ & 3 \\
\hline & & Aktif dan Kreatif & 4 \\
\hline & & $\begin{array}{l}\text { Sangat Aktif dan } \\
\text { Kreatif }\end{array}$ & 5 \\
\hline 3. & Kehadiran & $\begin{array}{l}\text { Banyak Alpa }(>5 \\
\text { hari/semester })\end{array}$ & 3 \\
\hline
\end{tabular}




\begin{tabular}{|c|c|c|c|}
\hline & & $\begin{array}{l}\text { Tidak Banyak Alpa } \\
\text { ( } \leq 5 \text { hari/semester) }\end{array}$ & 4 \\
\hline & & Selalu Hadir & 5 \\
\hline \multirow[t]{2}{*}{4.} & kepemimpin & Kurang memiliki & 3 \\
\hline & an & Memiliki & 5 \\
\hline \multirow[t]{5}{*}{5.} & Pelatihan & Tidak pernah & 1 \\
\hline & & $\begin{array}{l}\text { 1-2 Kegiatan } \\
\text { pelatihan }\end{array}$ & 2 \\
\hline & & $\begin{array}{l}\text { 3-5 Kegiatan } \\
\text { Pelatihan }\end{array}$ & 3 \\
\hline & & $\begin{array}{l}\text { 6-7 Kegiatan } \\
\text { Pelatihan }\end{array}$ & 4 \\
\hline & & $\geq 8$ Kegiatan Pelatihan & 5 \\
\hline \multirow[t]{3}{*}{6.} & Sosial & Kurang & 3 \\
\hline & & Baik & 4 \\
\hline & & Sangat Baik & 5 \\
\hline
\end{tabular}

Data-data yang telah dikumpulkan yang merupakan nilai guru-guru yang akan diolah dengan menggunakan metode TOPSIS pada penelitian ini dapat dilihat pada tabel 4 .

\begin{tabular}{ccccccc}
\multicolumn{7}{c}{ Tabel 4. Data Nilai Guru } \\
\hline Alternatif & C1 & C2 & C3 & C4 & C5 & C6 \\
\hline A1 & 4 & 3 & 5 & 5 & 5 & 4 \\
A2 & 3 & 3 & 5 & 5 & 5 & 4 \\
A3 & 3 & 5 & 5 & 3 & 5 & 5 \\
A4 & 4 & 3 & 5 & 5 & 4 & 4 \\
A5 & 3 & 3 & 3 & 5 & 3 & 4 \\
A6 & 3 & 3 & 3 & 5 & 5 & 5 \\
A7 & 3 & 3 & 3 & 5 & 4 & 5 \\
A8 & 4 & 5 & 5 & 3 & 5 & 5 \\
A9 & 3 & 3 & 4 & 5 & 5 & 5 \\
A10 & 3 & 3 & 3 & 5 & 3 & 5 \\
\hline
\end{tabular}

SPK metode Topsis ini memberikan keputusan alternatif, sedangkan keputusan akhir yang diambil masih ditentukan oleh pengambil keputusan. Sistem pendukung keputusan mengintegrasikan sumber daya intelektual dari individu dengan kemampuan komputer untuk meningkatkan kualitas formulasi keputusan. [8] [11]. TOPSIS akan merangking alternative berdasarkan prioritas nilai kedekatan relatif suatu alternative terhadap solusi ideal positif. Alternatif-alternatif yang dirangking selanjutnya dijadikan sebagai referensi bagi pengambil keputusan untuk memilih solusi terbaik.[12]-[15]

Tahapan yang dilakukan pada metode Topsis :

1. Membuat sebuah matriks keputusan. Matriks keputusan $X$ mengacu terhadap $m$ alternatif yang akan dievaluasi berdasarkan $n$ kriteria.

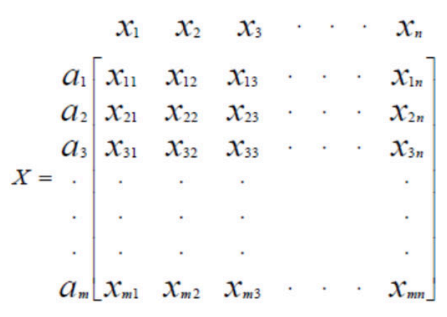

2. Membuat matriks keputusan yang ternormalisasi $\left(X_{i j}\right)$.

$R_{i j}=\frac{x_{i j}}{\sqrt{\sum_{i=1}^{m} x_{i j}^{2}}}$

dengan $i=1,2,3, \ldots, m$; dan $j=1,2,3, \ldots, n$; dimana $\mathrm{R} i j$ adalah elemen dari matriks keputusan yang ternormalisai $R, \mathrm{X}_{i j}$ adalah elemen dari matriks keputusan $X$.

3. Membuat matriks keputusan yang ternormalisasi terbobot dengan bobot $w=(1 w, 2 w, 3 w, \ldots, n w)$, dimana $w j$ adalah bobot dari kriteria ke $-j$ dan $\sum_{j=1}^{n} w j=1$ maka normalisasi bobot matriks $V$ adalah :

$\mathrm{V}_{\mathrm{ij}}=\mathrm{R}_{\mathrm{ij}} \mathrm{W}_{\mathrm{j}}$

dengan $\mathrm{i}=1,2,3, \ldots, \mathrm{m} ;$ dan $j=1,2,3, \ldots, n$. dimana $W$ ij : adalah elemen dari matriks keputusan yang ternormalisai terbobot $V$ $\mathrm{W} j$ : adalah bobot dari kriteria ke-j,

rij : adalah elemen dari matriks keputusan yang ternormalisai $R$.

4. Menentukan matriks solusi ideal dan matriks solusi ideal negative Solusi ideal positif dinotasikan $A^{+}$, sedangkan solusi ideal negatif dinotasikan $A$ - berikut ini adalah persamaan dari $A+$ dan $A$ - : 
a. $A+=\left\{(\max v i j \mid \mathrm{j} € \mathrm{~J}),\left(\min v i j \mid j € \mathrm{~J}^{\prime}\right), i=1\right.$, $2,3, \ldots, m\}$

$=\{v 1+, v 2+, v 3+, \ldots, v n+\}$

b. $A=\{(\min v i j \mid \mathrm{j} € J),(\max v i j \mid j \in J), i=1$, $2,3, \ldots, \mathrm{m}\}$

$=\{v 1-, v 2-, v 3-, \ldots, v n-\}$

$J=\{\mathrm{j}=1,2,3, \ldots, n$ dan $J$ merupakan himpunan kriteria keuntungan (benefit criteria) $\}$.

$J^{\prime}=\{\mathrm{j}=1,2,3, \ldots, n$ dan $J$ merupakan himpunan kriteria biaya (cost criteria) \}.dimana vij adalah elemen dari matriks keputusan yang ternormalisai terbobot $V, v+j(\mathrm{j}=1,2,3, \ldots, n)$ adalah elemen matriks solusi ideal positif, $v-j(\mathrm{j}=1,2,3, \ldots, n)$ adalah elemen matriks solusi ideal negatif.

5. Menghitung Separasi

a) $\mathrm{S}+$ adalah jarak alternatif dari solusi ideal positif didefinisikan sebagai:

$$
S_{i}^{+}=\sqrt{\sum_{j=1}^{n}\left(v_{i j}-v_{j}^{+}\right)^{2}}
$$

dengan $i=1,2,3, \ldots, m$

b) $S^{-}$adalah jarak alternatif dari solusi ideal negatif didefinisikan sebagai:

$$
S_{i}^{-}=\sqrt{\sum_{j=1}^{n}\left(v_{i j}-v_{j}^{-}\right)^{2}}
$$$$
\text { dengan } i=1,2,3, \ldots, m
$$

6. Menentukan nilai preferensi untuk setiap alternative Kedekatan setiap alternatif terhadap solusi ideal dihitung berasarkan rumus :

$V=\frac{D i^{-}}{D i^{+}+D i^{+}}, i=1,2,3, \ldots \ldots, m$

7. Merangking Alternatif.

Alternatif diurutkan dari nilai $C+$ terbesar ke nilai terkecil. Alternatif dengan nilai $C$ - terbesar merupakan solusi yang terbaik [16][20]

\section{HASIL DAN PEMBAHASAN 3.1. Hasil Pengujian TOPSIS}

Dari tabel di atas, dilanjutkan perhitungan menggunakan metode TOPSIS.

a. Matriks keputusan ternormalisasi

$\left|x_{1}\right|=\sqrt{4^{2}+3^{2}+3^{2}+4^{2}+4^{2}+3^{2}+3^{2}+3^{2}+3^{2}+3^{2}}$

$=10,5357$

$r_{11}=\frac{x_{11}}{\left|x_{1}\right|}=\frac{4}{10,5357}=0,3797$

$r_{21}=\frac{x_{21}}{\left|x_{1}\right|}=\frac{3}{10,5357}=0,2847$

$r_{31}=\frac{x_{31}}{\left|x_{1}\right|}=\frac{3}{10,5357}=0,2847$

$r_{41}=\frac{x_{41}}{\left|x_{1}\right|}=\frac{4}{10,5357}=0,3797$

$r_{51}=\frac{x_{51}}{\left|x_{1}\right|}=\frac{3}{10,5357}=0,2847$

$r_{61}=\frac{x_{11}}{\left|x_{1}\right|}=\frac{3}{10,5357}=0,2847$

$r_{71}=\frac{x_{21}}{\left|x_{1}\right|}=\frac{3}{10,5357}=0,2847$

$r_{81}=\frac{x_{31}}{\left|x_{1}\right|}=\frac{4}{10,5357}=0,3797$

$r_{91}=\frac{x_{41}}{\left|x_{1}\right|}=\frac{3}{10,5357}=0,2847$

$r_{101}=\frac{x_{51}}{\left|x_{1}\right|}=\frac{3}{10,5357}=0,2847$

Tabel 5. Matriks Ternormalisasi

\begin{tabular}{ccccccc}
\hline $\begin{array}{c}\text { ALT/ } \\
\text { KRIT }\end{array}$ & C1 & C2 & C3 & C4 & C5 & C6 \\
\hline A1 & 0.3797 & 0.2716 & 0.3758 & 0.3386 & 0.3536 & 0.2734 \\
A2 & 0.2847 & 0.2716 & 0.3758 & 0.3386 & 0.3536 & 0.2734 \\
A3 & 0.2847 & 0.4527 & 0.3758 & 0.2032 & 0.3536 & 0.3418 \\
A4 & 0.3797 & 0.2716 & 0.3758 & 0.3386 & 0.2828 & 0.2734 \\
A5 & 0.2847 & 0.2716 & 0.2255 & 0.3386 & 0.2121 & 0.2734 \\
A6 & 0.2847 & 0.2716 & 0.2255 & 0.3386 & 0.3536 & 0.3418 \\
A7 & 0.2847 & 0.2716 & 0.2255 & 0.3386 & 0.2828 & 0.3418 \\
A8 & 0.3797 & 0.4527 & 0.3758 & 0.2032 & 0.3536 & 0.3418 \\
A9 & 0.2847 & 0.2716 & 0.3007 & 0.3386 & 0.3536 & 0.3418 \\
A10 & 0.2847 & 0.2716 & 0.2255 & 0.3386 & 0.2121 & 0.3418 \\
\hline
\end{tabular}

b. Matriks keputusan terbobot

Matriks ternormalisasi dikalikan dengan bobot $W=[5,4,3,3,2,1]$

$y_{i j}=W_{i} * r_{i j}$

$\mathrm{y} 11=0,3797 \times 5=1,8983$

$\mathrm{y} 12=0,2716 \times 4=1,0864$

$\mathrm{y} 13=0,3758 \times 3=1,1275$

$\mathrm{y} 14=0,3386 \times 3=1,0159$

$\mathrm{y} 15=0,3536 \times 2=0,7071$

$\mathrm{y} 16=0,3234 \mathrm{x} 1=0,2734$ 
Tabel 6. Matriks Ternormalisasi Terbobot

\begin{tabular}{ccccccc}
\hline ALT/KRIT & $\mathbf{C 1}$ & $\mathbf{C 2}$ & $\mathbf{C 3}$ & $\mathbf{C 4}$ & $\mathbf{C 5}$ & $\mathbf{C 6}$ \\
BOBOT & $\mathbf{5}$ & $\mathbf{4}$ & $\mathbf{3}$ & $\mathbf{3}$ & $\mathbf{2}$ & $\mathbf{1}$ \\
\hline $\mathbf{A 1}$ & 1,8983 & 1,0864 & 1,1275 & 1,0159 & 0,7071 & 0,2734 \\
$\mathbf{A 2}$ & 1,4237 & 1,0864 & 1,1275 & 1,0159 & 0,7071 & 0,2734 \\
$\mathbf{A 3}$ & 1,4237 & 1,8107 & 1,1275 & 0,6096 & 0,7071 & 0,3418 \\
$\mathbf{A 4}$ & 1,8983 & 1,0864 & 1,1275 & 1,0159 & 0,5657 & 0,2734 \\
$\mathbf{A 5}$ & 1,4237 & 1,0864 & 0,6765 & 1,0159 & 0,4243 & 0,2734 \\
$\mathbf{A 6}$ & 1,4237 & 1,0864 & 0,6765 & 1,0159 & 0,7071 & 0,3418 \\
$\mathbf{A 7}$ & 1,4237 & 1,0864 & 0,6765 & 1,0159 & 0,5657 & 0,3418 \\
$\mathbf{A 8}$ & 1,8983 & 1,8107 & 1,1275 & 0,6096 & 0,7071 & 0,3418 \\
A9 & 1,4237 & 1,0864 & 0,9020 & 1,0159 & 0,7071 & 0,3418 \\
$\mathbf{A 1 0}$ & 1,4237 & 1,0864 & 0,6765 & 1,0159 & 0,4243 & 0,3418 \\
\hline
\end{tabular}

c. Matriks Solusi Ideal Positif

$y_{1}^{+}=\max \{1,8983 ; 1,4237 ; 1,4237 ; 1,8983$; 1,$4237 ; 1,4237 ; 1,4237 ; 1,8983 ; 1,4237$; $1,4237\}=1,8983$

$y_{2}^{+}=\max \{1,0864 ; 1,0864 ; 1,8107 ; 1,0864$; 1,$0864 ; 1,0864 ; 1,0864 ; 1,8107 ; 1,0864$; $1,0864\}=1,8107$

$y_{3}^{+}=\max \{1,1275 ; 1,1275 ; 1,1275 ; 1,1275$; 0,$6765 ; 0,6765 ; 0,6765 ; 1,1275 ; 0,9020$; $0,6765\}=1,1275$

$y_{4}^{+}=\max \{1,0159 ; 1,0159 ; 0,6096 ; 1,0159$; 1,$0159 ; 1,0159 ; 1,0159 ; 0,6096 ; 1,0159$; $1,0159\}=1,0159$

$y_{5}^{+}=\max \{0,7071 ; 0,7071 ; 0,7071 ; 0,5657$; 0,$4243 ; 0,7071 ; 0,5657 ; 0,7071 ; 0,7071$; $0,4243\}=0,7071$

$y_{6}^{+}=\max \{0,2734 ; 0,2734 ; 0,3418 ; 0,2734$; 0,$2734 ; \quad 0,3418 ; 0,3418 ; 0,3418 ; 0,3418$; $0,3418\}=0,3418$

d. Matriks Solusi Ideal Negatif

$y_{1}^{-}=\min \{1,8983 ; 1,4237 ; 1,4237 ; 1,8983$; 1,$4237 ; 1,4237 ; 1,4237 ; 1,8983 ; 1,4237$; $1,4237\}=1,4237$

$y_{2}^{-}=\min \{1,0864 ; 1,0864 ; 1,8107 ; 1,0864$; 1,$0864 ; 1,0864 ; 1,0864 ; 1,8107 ; 1,0864$; $1,0864\}=1,0864$

$y_{3}^{-}=\min \{1,1275 ; 1,1275 ; 1,1275 ; 1,1275$; 0,$6765 ; 0,6765 ; 0,6765 ; 1,1275 ; 0,9020$; $0,6765\}=0,6765$

$y_{4}^{-}=\min \{1,0159 ; 1,0159 ; 0,6096 ; 1,0159$; 1,$0159 ; 1,0159 ; \quad 1,0159 ; 0,6096 ; 1,0159$; $1,0159\}=0,6096$ $y_{5}^{-}=\min \{0,7071 ; 0,7071 ; 0,7071 ; 0,5657$; 0,$4243 ; 0,7071 ; 0,5657 ; 0,7071 ; 0,7071$; $0,4243\}=0,4243$ $y_{6}^{-}=\min \{0,2734 ; 0,2734 ; 0,3418 ; 0,2734$ 0,$2734 ; \quad 0,3418 ; \quad 0,3418 ; \quad 0,3418 ; \quad 0,3418$; $0,3418\}=0,2734$

Solusi ideal positif dan solusi ideal negatif : $\mathrm{A}^{+}=\{1,8983 ; 1,8107 ; 1,1275 ; 1,0159 ; 0,7071$; $0,3418\}$

$\mathrm{A}^{-}=\{1,4237 ; 1,0864 ; 0,6765 ; 0,6096$;

$0,4243 ; 0,2734\}$

e. Jarak nilai terbobot setiap alternatif terhadap solusi ideal positif

$D_{1}^{+}$

$=\sqrt{(1,8983-1,8983)^{2}+(1,8107-1,0864)^{2}+(1,1275-1,1275)^{2}}$
$+(1,0159-1,0159)^{2}+(0,7071-0,7071)^{2}+(0,3418-0,2734)^{2}$
$=0,7275$ $D_{2}^{+}$

$=(1,8983-1,4237)^{2}+(1,8107-1,0864)^{2}+(1,1275-1,1275)^{2}$

$=\sqrt{+(1,0159-1,0159)^{2}+(0,7071-0,7071)^{2}+(0,3418-0,2734)^{2}}$

$=0,8686$

$D_{3}^{+}$

$(1,8983-1,4237)^{2}+(1,8107-1,8107)^{2}+(1,1275-1,1275)^{2}$ $=\sqrt{ }+(1,0159-0,6096)^{2}+(0,7071-0,7071)^{2}+(0,3418-0,3418)^{2}$ $=0,6248$

$D_{4}^{+}$

$(1,8983-1,8983)^{2}+(1,8107-1,0864)^{2}+(1,1275-1,1275)^{2}$

$=\sqrt{+(1,0159-1,0159)^{2}+(0,7071-0,5657)^{2}+(0,3418-0,2734)^{2}}$

$=0,7411$

$D_{5}^{+}=$

$(1,8983-1,4237)^{2}+(1,8107-1,0864)^{2}+(1,1275-0,6765)^{2}$ $+(1,0159-1,0159)^{2}+(0,7071-0,4243)^{2}+(0,3418-0,2734)^{2}=$ 1,0188

$D_{6}^{+}$ $=\sqrt{(1,8983-1,4237)^{2}+(1,8107-1,0864)^{2}+(1,1275-0,6765)^{2}}$
$=0,9763$

$D_{7}^{+}$

$=\sqrt{(1,8983-1,4237)^{2}+(1,8107-1,0864)^{2}+(1,1275-0,6765)^{2}}$

$=\sqrt{+(1,0159-1,0159)^{2}+(0,7071-0,5657)^{2}+(0,3418-0,3418)^{2}}$ $=0,9865$

$D_{8}^{+}$

$(1,8983-1,8983)^{2}+(1,8107-1,8107)^{2}+(1,1275-1,1275)^{2}$ $\sqrt{+(1,0159-0,6096)^{2}+(0,7071-0,7071)^{2}+(0,3418-0,3418)^{2}}$ $=0,4064$

$D_{9}^{+}=$

$(1,8983-1,4237)^{2}+(1,8107-1,0864)^{2}+(1,1275-0,9020)^{2}$ $\sqrt{+(1,0159-1,0159)^{2}+(0,7071-0,7071)^{2}+(0,3418-0,3418)^{2}}=$ 0,8948

$D_{10}^{+}$

$(1,8983-1,4237)^{2}+(1,8107-1,0864)^{2}+(1,1275-0,6765)^{2}$

$=\sqrt{+(1,0159-1,0159)^{2}+(0,7071-0,4243)^{2}+(0,3418-0,3418)^{2}}$ $=1,0165$

f. Jarak nilai terbobot setiap alternatif terhadap solusi ideal negatif

$D_{1}^{-}$

$=\sqrt{(1,8983-1,4237)^{2}+(1,0864-1,0864)^{2}+(1,1275-0,6765)^{2}}$

$=\sqrt{+(1,0159-0,609)^{2}+(0,7071-0,4243)^{2}+(0,2734-0,2734)^{2}}$

$=0,8208$ 
$D_{2}^{-}$

$=\sqrt{\begin{array}{l}(1,4237-1,4237)^{2}+(1,0864-1,0864)^{2}+(1,1275-0,6765)^{2} \\ +(1,0159-0,609)^{2}+(0,7071-0,4243)^{2}+(0,2734-0,2734)^{2}\end{array}}$

$=0,6697$

$D_{3}^{-}$

$=(1,4237-1,4237)^{2}+(1,8107-1,0864)^{2}+(1,1275-0,6765)^{2}$

$=\sqrt{+(0,6096-0,609)^{2}+(0,7071-0,4243)^{2}+(0,3418-0,2734)^{2}}$

$=0,9015$

$D_{4}^{-}$

$=\sqrt{(1,8983-1,4237)^{2}+(1,0864-1,0864)^{2}+(1,1275-0,6765)^{2}}$

$=\sqrt{+(1,0159-0,609)^{2}+(0,5657-0,4243)^{2}+(0,2734-0,2734)^{2}}$

$=0,7834$

$D_{5}^{-}$

$(1,4237-1,4237)^{2}+(1,0864-1,0864)^{2}+(0,6765-0,6765)^{2}$

$=\sqrt{+(1,0159-0,6096)^{2}+(0,4243-0,4243)^{2}+(0,2734-0,2734)^{2}}$

$=0,4064$

$D_{6}^{-}$

$=(1,4237-1,4237)^{2}+(1,0864-1,0864)^{2}+(0,67655-0,6765)^{2}$

$=\sqrt{+(1,0159-0,6096)^{2}+(0,7071-0,4243)^{2}+(0,3418-0,2734)^{2}}$

$=0,4998$

$D_{7}^{-}$

$=\sqrt{(1,4237-1,4237)^{2}+(1,0864-1,0864)^{2}+(0,6765-0,6765)^{2}}$

$=\sqrt{+(1,0159-0,6096)^{2}+(0,5657-0,4243)^{2}+(0,3418-0,2734)^{2}}$

$=0,4357$

$D_{8}^{-}$

$=\sqrt{(1,8983-1,4237)^{2}+(1,8107-1,0864)^{2}+(1,1275-0,6765)^{2}}$

$=\sqrt{+(0,6096-0,6096)^{2}+(0,7071-0,4243)^{2}+(0,3418-0,526)^{2}}$

$=1,0188$

$D_{9}^{-}$

$=\sqrt{\begin{array}{c}(1,4237-1,4237)^{2}+(1,0864-1,0864)^{2}+(0,9020-0,6765)^{2} \\ +(1,0159-0,6096)^{2}+(0,7071-0,4243)^{2}+(0,3418-0,2734)^{2}\end{array}}$

$=0,5483$

$D_{10}^{-}$

$=\sqrt{(1,4237-1,4237)^{2}+(1,0864-1,0864)^{2}+(0,6765-0,6765)^{2}}$

$=\sqrt{\begin{array}{c}(1,4237-1,4237)^{2}+(1,0864-1,0864)^{2}+(0,6765-0,6765)^{2} \\ +(1,0159-0,6096)^{2}+(0,4243-0,4243)^{2}+(0,3418-0,2734)^{2}\end{array}}$

$=0,4121$

g. Nilai preferensi setiap alternatif

$$
\begin{aligned}
& V_{1}=\frac{0,8208}{0,8208+0,7275}=0,5301 \\
& V_{2}=\frac{0,6697}{0,6697+0,8686}=0,4354 \\
& V_{3}=\frac{0,9015}{0,9015+0,6248}=0,5906 \\
& V_{4}=\frac{0,7834}{0,7834+0,7411}=0,5139 \\
& V_{5}=\frac{0,4064}{0,4064+1,0188}=0,2851 \\
& V_{6}=\frac{0,4998}{0,4998+0,9763}=0,3386 \\
& V_{7}=\frac{0,4357}{0,4357+0,9865}=0,3063 \\
& V_{8}=\frac{1,0188}{1,0188+0,4064}=0,7149 \\
& V_{9}=\frac{0,5483}{0,5483+0,8948}=0,3800
\end{aligned}
$$

$$
V_{10}=\frac{0,4121}{0,4121+1,0165}=0,2885
$$

h. Pengurutan berdasarkan nilai prefensi yang didapatkan, dari yang terbesar sampai yang terkecil.

Tabel 7. Pengurutan Nilai Prefensi Alternatif

\begin{tabular}{cc}
\hline Alternatif & Nilai Prefensi \\
\hline A8 & 0,7149 \\
A3 & 0,5906 \\
A1 & 0,5301 \\
A4 & 0,5139 \\
A2 & 0,4354 \\
A9 & 0,3800 \\
A6 & 0,3386 \\
A7 & 0,3063 \\
A10 & 0,2885 \\
A5 & 0,2851 \\
\hline
\end{tabular}

Berdasarkan hasil perhitungan diatas dapat diketahui bahawa guru yang terbaik $\mathrm{A} 8$ dengan nilai 0,7149 , guruterbaik kedua A3 dengan nilai 0,5906, dan guru terbaik ketiga A1 dengan nilai 0,5301 .

\subsection{Membangun Sistem SPK}

a. Use Case Diagram

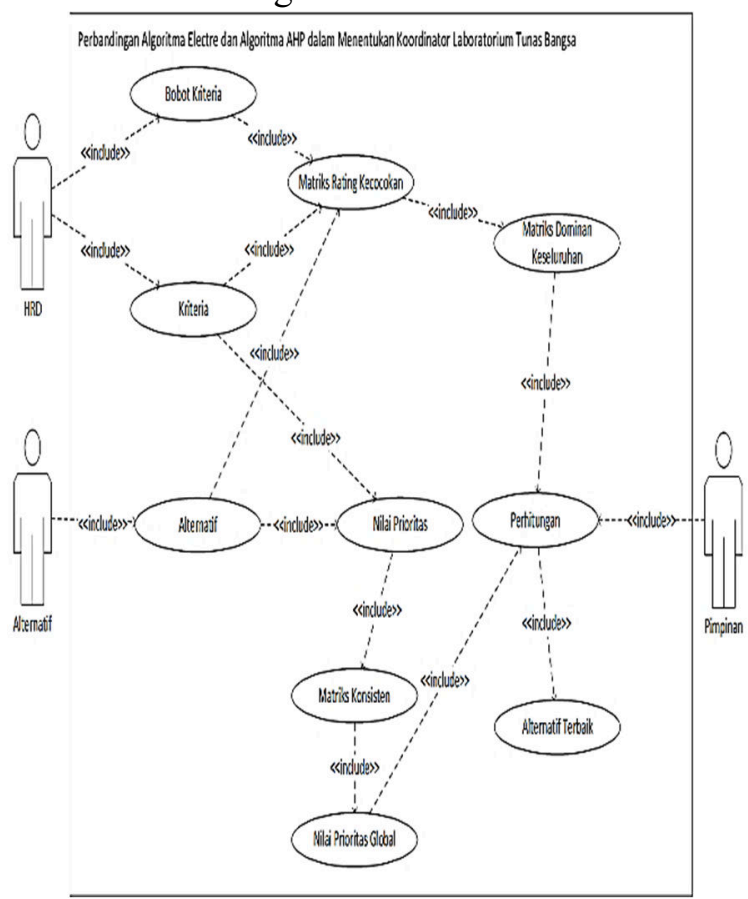

Gambar 2. Use Case Diagram 
b. Activity Diagram

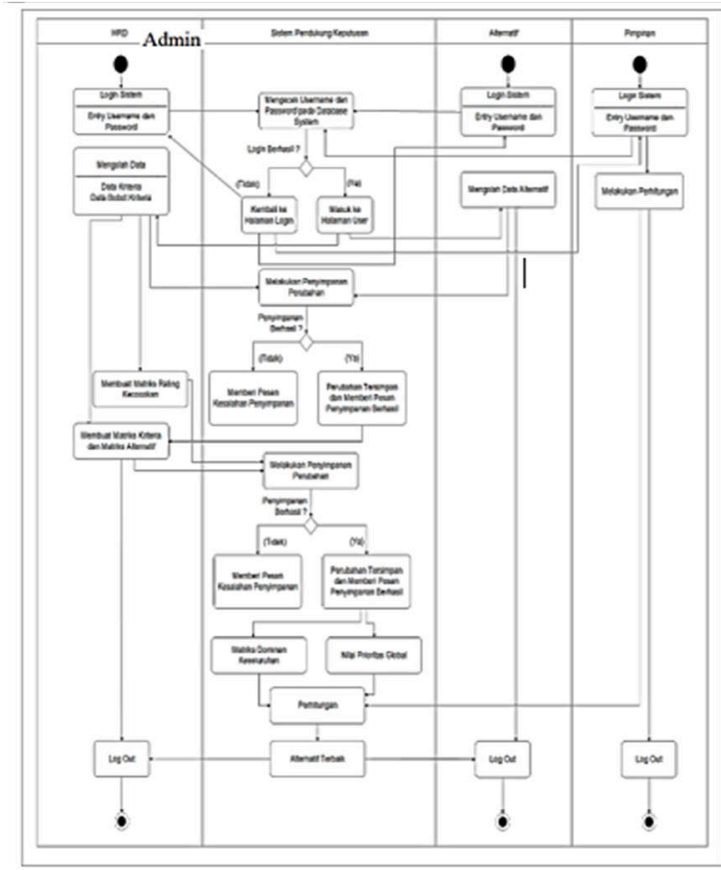

Gambar 3. Activity Diagram

c. Implementasi SPK



Gambar 4. Hasil Perhitungan dengan SPK

d. Perbandingan hasil perhitungan TOPSIS dengan cara manual dengan aplikasi berbasis web
Tabel 8. Hasil Perhitungan Manual dan Aplikasi SPK

\begin{tabular}{cccccc}
\hline & Manual & & \multicolumn{3}{c}{ Aplikasi SPK berbasis web } \\
\hline \multirow{2}{*}{ Alternatif } & $\begin{array}{c}\text { Nilai } \\
\text { Akhir }\end{array}$ & \multirow{2}{*}{ Ranking } & Alternatif & $\begin{array}{c}\text { Nilai } \\
\text { Akhir }\end{array}$ & Ranking \\
\hline A1 & 0,5301 & 3 & A1 & 0,5301 & 3 \\
A2 & 0,4354 & 5 & A2 & 0,4354 & 5 \\
A3 & 0,5906 & 2 & A3 & 0,5906 & 2 \\
A4 & 0,5139 & 4 & A4 & 0,5139 & 4 \\
A5 & 0,2851 & 10 & A5 & 0,2851 & 10 \\
A6 & 0,3386 & 7 & A6 & 0,3386 & 7 \\
A7 & 0,3063 & 8 & A7 & 0,3063 & 8 \\
A8 & 0,7149 & 1 & A8 & 0,7149 & 1 \\
A9 & 0,3800 & 6 & A9 & 0,38 & 6 \\
A10 & 0,2885 & 9 & A10 & 0,2885 & 9 \\
\hline
\end{tabular}

\section{KESIMPULAN}

Berdasarkan hasil pengujian dilakukan bahwa sistem yang dibangun dengan menggunakan metode TOPSIS dapat membantu pihak pengambil keputusan dalam menentukan pemberian reward Guru Terbaik pada SMK Swasta 1 HKBP Pematangsiantar. Metode TOPSIS mampu menganalisis pemberian reward guru dengan baik. Dan memberikan rekomendasi guru penerima reward yang terukur dan objektif. Berdasarkan hasil analisis manual dan pengujian dengan sistem SPK yang dibangun bahwa alternatif atas nama $\mathrm{A} 8$ adalah altertatif tertinggi pertama dengan nilai rekomendasi 0,7149, alternatif terendah adalah A10 dengan nilai rekomendasi 0, 2851.

\section{REFERENSI}

[1] R. Doni, F. Amir, and D. Juliawan, "Sistem Pendukung Keputusan Kenaikan Jabatan Menggunakan Metode Technique for Order Preference by Similarity to Ideal Solution (TOPSIS)," Pros. Semin. Nas. Ris. Inf. Sci., vol. 1, no. September, p. 69, 2019, doi: 10.30645/senaris.v1i0.9.

[2] C. Surya, "Penilaian Kinerja Dosen Menggunakan Metode TOPSIS (Studi Kasus : Amik Mitra Gama)," J. RESTI (Rekayasa Sist. dan Teknol. Informasi), vol. 2, no. 1, pp. 322-329, 2018, doi: 10.29207/resti.v2i1.119.

[3] O. J. Harmaja and M. S. Hutauruk, "Sistem Penunjang Keputusan Penerima Program Keluarga Harapan Dengan 
Menggunakan Metode Topsis," J. Tek. Inf. dan Komput., vol. 3, no. 2, p. 37, 2021, doi: 10.37600/tekinkom.v3i2.134.

[4] A. M. Dawis, "Sistem Pendukung Keputusan Pemberian Reward Pegawai Menggunakan Metode TOPSIS," J. Ilm. SINUS, vol. 18, no. 1, p. 11, 2020, doi: 10.30646/sinus.v18i1.429.

[5] A. Eryzha, S. Solikhun, and E. Irawan, "Sistem Pendukung Keputusan Rekomendasi Pemilihan Smartphone Terbaik Menggunakan Metode Topsis," KOMIK (Konferensi Nas. Teknol. Inf. dan Komputer), vol. 3, no. 1, pp. 610-616, 2019, doi: 10.30865/komik.v3i1.1668.

[6] I. P. S. Handika and P. P. Santika, "Rekomendasi Pelamar Kerja Berdasarkan Spesifikasi Lowongan Menggunakan Metode Anp Topsis," SCAN - J. Teknol. Inf. dan Komun., vol. 15, no. 1, pp. 1-9, 2020, doi: 10.33005/scan.v15i1.1846.

[7] T. Kristina, "Sistem Pendukung Keputusan Dengan Menggunakan Metode TOPSIS Untuk Pemilihan Lokasi Pendirian Grosir Pulsa," Paradigma, vol. 20, no. 1, pp. 8-12, 2018.

[8] G. Wibisono, A. Amrulloh, and E. Ujianto, "Penerapan Metode Topsis Dalam Penentuan Dosen Terbaik," Ilk. J. Ilm., vol. 11, no. 2, pp. 102-109, 2019, doi: 10.33096/ilkom.v11i2.430.102-109.

[9] P. A. W. Santiary, P. I. Ciptayani, N. G. A. P. H. Saptarini, and I. K. Swardika, "Jurnal Pengertian Topsis," vol. 5, no. 5, pp. 621-628, 2018, doi: 10.25126/jtiik2018551120.

[10] W. Yusnaeni, R. Ningsih, and T. Misriati, "Pemilihan Suplier Bahan Baku Dengan Metode Technique for Order Performance by Similarity to Ideal Solution(TOPSIS)," Semin. Nas. Sains dan Teknol., no. November, pp. 1-7, 2017.

[11] R. Setiawan, A. Arini, and L. K. Wardhani, "SMART and TOPSIS Method For Determining The Priority Of Screen Printing," SinkrOn, vol. 4, no. 2, p. 151, 2020, doi: 10.33395/sinkron.v4i2.10471.

[12] D. Nababan, R. Rahim, and I. Teknologi Medan, "Sistem Pendukung Keputusan Reward Bonus Karyawan Dengan Metode
Topsis," J. Inf. Syst. Dev., vol. 3, no. 1, pp. 2528-5114, 2018, [Online]. Available: https://ejournal.medan.uph.edu/index.php /isd/article/view/185.

[13] N. D. Palasara and T. Baidawi, "Penerapan Metode Topsis Pada Peningkatan Kinerja Karyawan," $J$. Inform., vol. 5, no. 2, pp. 287-294, 2018, doi: $10.31311 /$ ji.v5i2.4234.

[14] N. Chaniago and A. Sindar, "SPK Penilaian Hasil Belajar Siswa Menggunakan Metode TOPSIS," vol. 9, pp. 41-48, 2020.

[15] I. Muzakkir, "Penerapan Metode Topsis Untuk Sistem Pendukung Keputusan Penentuan Keluarga Miskin Pada Desa Panca Karsa Ii," Ilk. J. Ilm., vol. 9, no. 3, pp. 274-281, 2017, doi: 10.33096/ilkom.v9i3.156.274-281.

[16] K. Purwasih and R. Nidia, "Penerapan Metode TOPSIS Untuk Pemilihan Siswa Berprestasi Pada SMPN 2 Barambai," Jutisi, vol. 6, no. 2, pp. 1497-1502, 2017, [Online]. Available: http://ojs.stmikbanjarbaru.ac.id/index.php/jutisi/article/v iew/246/232.

[17] G. Y. Prastoto, "Sistem Pendukung Keputusan Pembelian Alat Outdoor Metode Topsis," 2019.

[18] G. S. Mahendra, "Metode Ahp-Topsis Pada Sistem Pendukung Keputusan Penentuan Penempatan Atm," JST (Jurnal Sains dan Teknol., vol. 9, no. 2, 2020, doi: 10.23887/jst-undiksha.v9i2.24592.

[19] E. Nurelasari and E. Purwaningsih, "Sistem Pendukung Keputusan Pemilihan Perumahan Terbaik dengan Metode TOPSIS Housing Selection Decision Support System Using the TOPSIS Method," vol. 08, no. 4, pp. 317-321, 2020, doi: 10.26418/justin.v8i4.41036.

[20] H. Hertyana, "Sistem Pendukung Keputusan Seleksi Pemilihan Perguruan Tinggi Menggunakan Metode Topsis," $J$. Pilar Nusa Mandiri, vol. 15, no. 1, pp. 97102, 2019, doi: 10.33480/pilar.v15i1.223. 